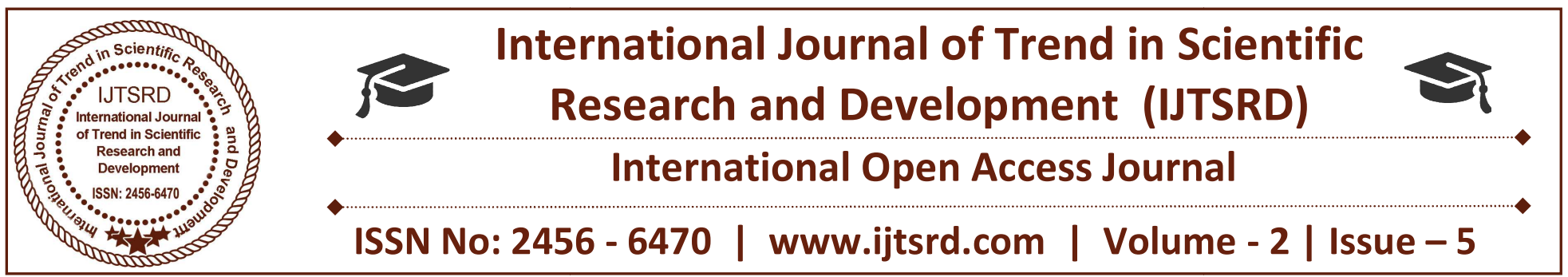

\title{
Reducing Financial Leakages Through Effective Transparency and Accountability Mechanism: A Necessary Tool to Accelerate Sustainable Economic Development
}

\author{
Adekunle, Dada Surajudeen ${ }^{1}$, Odutola, Oluyemi Akanbi ${ }^{1}$, \\ Akomolafe, Johnson Adewale ${ }^{1}$, Adegbite, G. Adewale ${ }^{2}$ \\ ${ }^{1}$ Department of Accountancy, ${ }^{2}$ Department of Marketing \\ Ogun State Institute of Technology, Igbesa, Ogun State, Nigeria
}

\section{ABSTRACT}

Nigeria as a nation is bedevilled with underdevelopment making it being referred to as either developing or under-developed nation despite huge revenue made from oil, tax and other revenue sources. The underdevelopment is blamed largely on lack of adequate financial resources to execute projects included in annual budget. However, financial experts and economists have maintained that Nigeria is blessed with enough resources to develop the nation only that the resources are being diverted to unauthorized routes or misappropriated by dubious public servants in collaboration with corrupt politicians due to financial accountability and transparency loopholes in the public financial management system of the nation. This view is as a result of unprecedented developmental projects embarked upon by the current administration despite financial leakages discovered in the system. The question remains that could entrenchment of effective accountability and transparency continue for a long while in public service to ensure sustainable economic development? The study is therefore embarked upon to identify how reducing financial leakages through effective transparency and accountability mechanism in Nigeria is possible to accelerate sustainable economic development. This is followed by review of relevant literature especially on public financial management theories relating to accountability/transparency and economic development. The data were then collected using secondary source and presented in frequency table showing various variables and their corresponding figures. The data were extracted from the Bulletins of
Federal Ministry of Finance, Central Bank of Nigeria and national Bureau of Statistics (NBS). The data were then subjected to analytical processing using regression analysis through Statistical Package for Social Sciences (SPSS). The study findings show that various strategies put in place by the current administration blocking financial leakages in the country have been able to ensure and accelerate economic development in the country while extending same to states and local governments including agencies which are yet to key-in to the policies would ensure sustainable economic development and restore the lost glory of the Country.

Keywords: financial leakages, transparency, accountability, economic development.

\section{INTRODUCTION}

In any organized society, the role of government in maintenance of law and order including carrying out of developmental projects is very critical. To carry out these tasks, governments at various levels in the public sector have to generate resources (money) and provide certain goods and services which are mainly collective services, quasi-collective services and utilities for the well-being of the citizenry. The resources are limited and therefore they are aggregated as "funds "monies or cash and when the funds are voted or allocated for operations, programmes or projects, the resources (funds) have to be used for that purpose wholly and timely. This is the essence of control through statutes and regulations. Public revenue and expenditure are usually contained 
in the government annual budget. The essence of the budget is to monitor accruing revenue and its application for efficient allocation of resources. The management of the resources is also delegated to others on behalf of the government hence there is need for probity and accountability. The strategies and control techniques put in place must allow for enforceability, uniformity of practices and compliance. The citizens have to be informed about the results of operations through published financial statements of Government(s) for review and remedial action. However, this control measure has been neglected by most government institutions

Financial malpractices such as deliberate and intentional embezzlement of government revenue, inflation of contract fees; non availability to produce payment voucher for monies paid out and many other dubious practice abound in the public sector making it the toast of unethical and fraudulent people. Nonretirement of impress advances collected by some government officials on behalf of other agencies; institutionalization of various forms of corrupt and fraudulent practices characterize the financial situation in most government institutions and agencies in Nigeria. This has reduced drastically the impact of government on community development and project execution as monies set aside for such projects are diverted by most civil servants especially the senior ones. It is gradually defeating the justification forthe existence of government. Hence, the phenomenon cannot be allowed to continue indefinitely if we want governments to serve as a viable instrument for society transformation and for the delivery of social services to the people. There is, therefore, the need to caution, control and ensure application of appropriate sanctions so as to reduce this ugly phenomenon in public service to a minimum level (Elekwa\&Okechukwu, 2014).

The scenarios of diversion of public fund show that there was problem of transparency and accountability in managing the resources of the state by those in charge. As a result of the diversion of public fund from public pockets to private pockets, there have been very low developmental projects across the country owing to lack of adequate resources to execute the projects. Therefore, this paper intends to justify the need for institutionalization of transparency and accountability in the management of public fund to hasten societal development and reduce revenue leakages

\section{Literature Review}

Disturbed by the high rate at which resource-rich African countries lose huge revenues through corruption, illegal transfers of profits and money laundering abroad, the African Union (AU) has asked African leaders to openly declare their assets and subject their wealth to public scrutiny. A report on Illicit Financial Flows from Africa, compiled by an AU panel led by former South African President Thabo Mbeki, said Africa loses an estimated \$60billion (about N10.08trillion) annually through such transfers. The report was presented in April 2015 at a summit in Addis Ababa, Ethiopia. The report has stirred massive concerns in Nigeria, which is said to account for over $\$ 40.9$ billion (about N6.87trillion), or 68 per cent of the total figure. Cumulatively, Nigeria also topped the list of ten African countries with highest incidence of illicit financial transfers between 1970 and 2008, recording about \$217.7billion (about $\mathrm{N} 36.57$ trillion), or $30.5 \%$ of the total in the continent. The issue of accountability and probity by top government officials has always been a source of serious concern in Nigeria, particularly with former President Good luck Jonathan repeatedly refusing to publicly declare his and other subordinates' assets. Mostly nowadays, the administration of President Muhammadu Buhari has continued to reel out figures of unaccounted revenues. These include N3.8 trillion allegedly withheld by the Nigerian National Petroleum Corporation (NNPC) out of the N8.1 trillion the country earned from crude oil sales between 2012 and 2015. Others are N109.7 billion royalty from oil companies, allegedly not remitted by the Department of Petroleum Resources (DPR); unaccounted N183 billion by the Niger Delta Development Commission (NDDC) and other \$13 billion dividends from the Nigeria Liquefied Natural Gas (NLNG). Also, on the seeming endless list are unapproved withdrawals of $\$ 2.1$ billion from the Excess Crude Account (ECA); \$1 billion allegedly withdrawn from public treasury for Jonathan's campaign and an alleged $\$ 6$ billion stolen by a former minister, among others (Emeh, Chukwurah\& Iheanacho, 2015). With these cases, it is glaring that lack of accountability has abetted the free revenue leakages in the public sector and so need urgent stoppage to move the nation forward.

\subsection{Concept of Revenue}

Revenue is a major factor in the income statement of a company or country, as it gives an idea of the financial standing of that company or country or 
government institution. The Investopedia (2013) sees revenue as the amount of money that a company actually receives during a specific period, including discounts and deductions for returned merchandise. Revenue is seen here as the gross receipts by a company or public institution regardless of the net profit or surplus within a given period. Revenue may also refer to business income in general, or it may refer to the amount, in a monetary unit, received during a period of time, as in last year, Company or Government A had a revenue of N42 billion. Revenue in accounting is often referred to as the 'top line' due to its position on the income statement at the very top (Wikipedia, 2012).

In a similar vein, the Investopedia (2013) sees revenue as a total amount of money received by a company or government for goods sold or services provided during a certain period. It includes all net sales, exchange of assets, interest and any other increase in owners' equity and is calculated before any expenses are subtracted. It notes that for the government, the increase in assets of governmental funds do not increase liability or recovery of expenditure. This revenue is obtained from taxes, licenses and fees. Revenue is an important tool of the fiscal policy of the government and it is the opposite factor of government spending (Wikipedia, 2012). Generally, government the world over earns revenue from taxes, non- tax income and capital receipts (Nwekeaku, 2013).

Public revenue could be defined as the funds generated by the government to finance its activities. In other words, revenue is the total fund generated by government (Federal, state, local government) to meet their expenditure for a fiscal year. This refers also to the grand total of money of income received from the source of which expenses are incurred. Revenue could be internal or external revenue. The Longman dictionary of contemporary English (1995) defined revenue as money that a business or an organization receives over a period of time especially from selling goods or services. It also described revenue as money that government receives from tax.

Advance learning dictionary of current English (1992), defined revenue as the total annual income of the state collected for public use. It further described itas income, derived from taxation for running of the state affairs and managing the public finance. In relation to this, there are two aspect of finance -
Income and Expenditure. In other words income and expenditure are the sources of fund and utilization respectively. Fayemi (1991) defined revenue as all pools of income to government such as taxes, rates, fees, fines, duties, penalties, rents, dues, proceeds and other receipt of government to which the legislature has the power of appropriation. He further classified government revenue into two kinds -recurrent revenue and capital revenue (Edogbanya\& Sule, 2013).In this piece, revenue can be briefly described as the totality of income generated by government or any of its agencies for the purpose of carrying out government duties.

\subsection{Concept of Transparency and Accountability}

Transparency is about shedding light on rules, plans, processes and actions. It is knowing why, how, what and how much. Transparency ensures that public officials, civil servants, managers, board members, and businessmen act visibly and understandably and report on their activities. -Transparency International

Accountability is defined as the obligation of powerholders to take responsibility for their actions. Power holders refer to those who hold political, financial or other forms of power and include officials in Government, private corporations, international financial institutions and CSOs. - World Bank (Olawale, 2016). This means accountability relates to the people vested with resources to be able to account for how they utilize the resources assigned to them. On the other hand, transparency indicates that there should be openness in the management and allocation of resources so as to be able to ensure good and sustainable development. In general, transparency implies openness, communication and accountability. With regard to the public services, it means that holders of public office should be as open as possible about all the decisions and actions they take, they should give reasons for their decisions and restrict information only when the wider public interest demands it (Chapman, 2000). Radical transparency in management demands that all decision making should be carried out publicly (Enofe, Aigboduwa, Audu\&Idemudia, 2015).

Accountability is all about being answerable to those who have invested their trust, faith, and resources to you. Adegbite (2010) defined accountability as the obligation to demonstrate that work has been conducted in accordance with agreed rules and standards and the officer reports fairly and accurately 
on performance results vis-à-vis mandated roles and or/plans. It means doing things transparently in line with due process and the provision of feedback. Johnson (2004) says that public accountability is an essential component for the functioning of our political system, as accountability means that those who are charged with drafting and/or carrying out policy should be obliged to give an explanation of their actions to the public (Omodero\& Okafor,2016).

According to Makinde (2003), accountability will orchestrate a proper public spending and increase the greatest good for the greatest number of citizens in the long run. Accountability or, more precisely, 'being accountable', is seen as a virtue, as a positive quality of organizations or officials. Along this path, accountability studies usually focus on normative matters vis-a-vis on the assessment of the active behaviour of public agents (Boven, 2007). This justification is problematic because of lack of universal agreement on what constitutes accountable behavior. But in ameliorating this problem, O'Connell (2005) opines that accountability was present when public services have a high quality, at a low cost and are performed in a courteous manner. Koppell (2005) identifies five different dimensions of accountability along this line thus- transparency, liability, controllability, responsibility and responsiveness (Apeloko\& Adesopo, 2017). For accountability to be possible, these essentials need to be present in someone or an institution

\subsection{Revenue Leakages}

Ideally, the public accounting system provides timely information about actual spending on various budget items and programmes, and the reports accurately capture what the intended users receive. This is not often the case in low-income countries especially in Nigeria. Typically the accounting system functions poorly as institutions enhancing government institutions accountability are weak, and there are few (if any) incentives to maintain adequate records at different levels of government. Consequently, little is known about the process of transforming budget allocations into services within most sectors (Reinikka $\&$ Svensson, 2001). The inability of the government resources or revenue to be used purely for government works or taken into government custody fully especially the diverted portion for unauthorized applications and usage constitute revenue leakage.
Data on official budget allocations are typically the only source of information on public spending in lowincome countries. Unfortunately, such information poorly predicts what the intended beneficiaries actually receive in terms of resources and services. This is particularly so in countries with weak institutions. Surveying the supply side of service delivery can provide a useful reality check. In this paper, there is a need for an innovative survey tool to be assessed for possible implementation to gauge the extent to which public resources actually filter down to the intended facilities. The survey would compare disbursed flows from the central government (intended resources) with the resources actually received by the intended beneficiaries so as to determine the extent of the leakage (Reinikka \& Svensson, 2001).

\subsection{Empirical findings}

To the extent diverted funds are used for private gain (by government officials), this paper also provides quantitative attempt to systematically measure corruption in basic service delivery systems. In study of Reinikka \& Svensson (2001), their findings provide new insight into an area almost exclusively studied using cross-country data. Their results suggest that a systematic effort to increase the ability of citizens to monitor and challenge abuses of the system, and inform them about their rights and entitlements, are important aspects in controlling corruption (Reinikka \& Svensson, 2001).

The Nigerian society is filled with stories of wrong practices such as stories of ghost workers on the pay roll of Ministries, Extra-ministerial Departments and Parastatals, frauds, embezzlements and setting ablaze of offices housing sensitive documents and corruption are found everywhere in the country (Okwoli, 2004). According to Bello (2001), huge amount of Naira is lost through one financial malpractice or the other in Nigeria, which to say the least, drains the nation's meager resources through fraudulent means with farreaching and attendant consequences on the development or even socio-economic or political programmes of the nation. Billions of Naira is lost in the public sector every year through fraudulent means. This represents only the amount that is ferreted out and made public. Indeed much more substantial or huge sums are lost in undetected frauds or those that are for one reason or the other hushed up. Appah and 
Appiah (2010) argues that cases of fraud is prevalent in the Nigerian public sector that every segment of the public service, could seem to be involved in one way or the other in some of these nasty acts (Omodero\& Okafor,2016).

The bane of public sector financial mismanagement in Nigeria started since the oil boom years a period under which there existed structurally weak control mechanism, which create a variety of loopholes that have tended to facilitate and sustain corrupt practices. This is coupled with the fact that there is a near total absence of the notion and ethics of accountability in the conduct of public affairs in the country (Bello, 2001).

Okoh and Ohwoyibo (2009) opine that accountability reflects the need for government and its agencies to serve the public effectively in accordance with the laws of the land. Appah (2010) point out that with the number and monetary value of public sector activities has increased substantially. This increase in activities has brought with it an increased demand for accountability of public officers who manage these activities of the public. Achua (2009) says "serious consideration is being given to the need to be more accountable for the often vast amounts of investment in resources at the command of governments, which exercise administrative and political authority over the actions and affairs of political units of people. Government spending is a very big business and the public demands to know whether the huge outlays of money are being spent wisely for public interests". Accountability is a fundamental value for any political system. Citizens should have the right to know what actions have been taken in their name, and they should have the means to force corrective actions when government acts in an illegal, immoral, or unjust manner (Peters, 1999). Accountability is also important for government (Omodero\& Okafor, 2016). It provides government with the means of understanding how programmes may fail and finding ways that can make programmes perform better. Kaufman (2005) argues that an emphasis on accountability by citizens is one aspect of the growing emphasis on eliminating corruption and promoting transparency in government. However, the issue of accountability in Nigeria is a fundamental problem because of the high level corruption in all levels of government in the country. The Transparency International global Corruption Perception Index in October 2010 ranked Nigeria 134 from its 130 position in 2009 and 121 in 2008. The $2010 \mathrm{CPI}$, drawn on a scale from 10 (highly clean) to 0 (highly corrupt), showed that Nigeria scored 24, and is ranked 134 amongst the 178 countries surveyed. In its 2017 report released in February 2018, it ranked Nigeria $148^{\text {th }}$ position among 180 countries considered. This sorry situation of Nigeria's lack of financial accountability in the public sector provided the desire for this paper to examine the accountability of public officers in the management of the financial resources of the country and means of achieving efficient, accountable and transparent society through a robust control like that of Denmark, New Zealand and Singapore that ranked top in the CPI grading (Omodero\& Okafor, 2016).

Fayol (1916) defined control as "verifying whether everything occurs in conformity with the plan adopted, the instructions issued, and principles established.' It has for its object the pointing out of errors and weaknesses in order to rectify them and prevent their recurrence. It operates on everything, people and actions. In any organization, control springs from supervision itself, i.e., it is carried by the head of the organization and his principal lieutenants along the scalar chain in the course of the supervision exercised by them. But in large-scale organization where the volume and complexity of control operations is considerable, separate control units or officer becomes necessary. They are known by various designations control bureaus, inspectorates, controllers, inspectors and so forth.

Control is essentially an administrative function, but to be comprehensive and effective, it must flow through several channels and takes several forms. Fayol mentioned five such channels. Firstly, from the commercial point of view (in case of business administration), control must ensure the checking of incoming and outgoing material as to quantity, quality and price, and see that stores records are kept properly and promises duly honoured. Secondly, from the technical standpoint, control watches the progress, of operations, their results and shortcomings and ensures the proper maintenance of personnel and equipment.

Thirdly, there is financial control the object of which is to secure compliance with the financial policy of the organization as expressed through the budget and to see that adequate funds are provided and economically used. Fourthly, there is control of security. It consists of procedures adopted for 
protecting property, funds, and personnel from damage and harm. Lastly, there is control of accounting to ensure that the essential documents and figures are quickly available, give a clear picture of the state of affairs, and that account books and statistics are adequately and properly maintained for purposes of audit. The success of the control techniques depend on their compliance with a number of specific standard (Elekwa\& Okechukwu, 2014).

In Aiyede's (2011) view, an institution is an enduring collection of formal laws and informal rules, norms, customs, codes of conduct and organized practices that shape and govern human interaction. It sometimes also entails downsizing, effective or judicious use of scarce resources to achieve huge outcome, curbing/curtailing poor decision making processes, management of staff welfare conditions, and boosting of weakened accountability designs (Olubunmi\& Adesopo, 2017).

In a general term, concrete public service reforms that were found to be in operation within the period understudy were highlighted (Adegoroye, 2006; Ayeni, 2008).All these arrangements were subsumed under four key areas thus: budgeting and financial management embracing procurement system, institutionalization of fiscal responsibility and accounting reforms. The second is the accountability reform, which entails the institution of due process, transparency and accountability in government transactions, establishment of service charters and institutionalization of compliance enforcement. The second stage just mentioned constitutes the focus of the study which includes the various identified mechanisms for its attainment (Olubunmi\& Adesopo, 2017).

Third, there is human resource management aspect of the reform with certain modalities for achieving the same: personnel record and payroll clearing, staff cadre reviews, remodelling the recruitment and promotion pattern, installation of new performance management scheme, professionalism, pay return as a strategic plan of action, capacity development and training and changes in organizational culture. Operation and systems, which constitute the fourth aspect, involves organizational restructuring and right-sizing, work process re-design and ICT application (Olubunmi \& Adesopo, 2017). Therefore, there is need for seriousness on the part of the government to engage morally sound person to champion the course of transparency and accountability in order to reduce the level of revenue leakages.

\section{Method}

Using Model adopted from Omodero \& Okafor (2016) which was the Efficiency of public sector expenditure (EPSE ) model (proxied by total revenue generated by government) as the independent variable while expenditure have been used as dependent variables. The model is therefore specified thus:

$\mathrm{Y}(\mathrm{E})=\alpha+\mathrm{R} \beta \mathrm{t}+\varepsilon \mathrm{t}$

Where;

$\mathrm{Y}=$ Efficiency of public sector expenditure

$\mathrm{R} \beta \mathrm{t}=$ Revenue

$\alpha=$ the parameter which represents the intercept $\beta, \beta$ $=$ The regression parameters are to be used in determining the significance of the effect of the independent variable on the dependent variable $Y, \varepsilon=$ Random disturbance term. These include the variables which (although not specified) in this model may also affect efficiency of public sector expenditure on accountability. They include transparency, government policies, political instability, corruption, fraud, tax evasion etc. The implications of efficiency of public sector expenditure on accountability are to be measured in billions Naira.

\section{Conclusion and Recommendations}

The practice of lack of adequate accountability and transparency which necessitates prevalence of revenue leakages in public sector is alarming nowadays going by realities of what goes into the pockets of individuals at the expense of the State. This has greatly thwarted governmental efforts at developing the nation rapidly. The accounting professionals in Nigeria and other stakeholders have a long way to go in restoring the lost glory in the nation public affairs. The repeated ranking of Nigeria as one of the most corrupt nations is due to the uncontrolled corruption in the public sector especially the juicy ones such as Tax Collectors, Petroleum Corporations, Port Authority, Customs, Police, Immigration, Road Safety etc. We have the vision and visionary leaders; we only need the machinery to commence the journey and a Single President or Governor without civil servants supporting cannot solve the problem. There is, therefore, the need for re-orientation for government workers to see the reason for them to reduce their level of corruption and embrace 
accountability and transparency in order to hasten our national development as against individual egocentrism. The government should also institutionalize anti-corruption war so that regardless of the suspect or criminal link to the government, justice would be fought to the fullest.

\section{REFERENCES}

1. Adegbite, E. O. (2010). "Accounting, Accountability and National Development", Nigerian Accountant, 43(1): 56-64.

2. Bello, S. (2001). 'Fraud Prevention and Control in Nigerian Public Service: The need for a Dimensional Approach", Journal of Business Administration, 1(2): 118-133.

3. Edogbanya, Adejoh \& Mr. Ja'afaru G. Sule (2013). Revenue Generation: It's Impact on Government Developmental Effort (A Study of Selected Local Council in Kogi East Senatorial District). Global Journal of Management and Business Research Administration and Management, Volume 13 Issue 4 Version 1

4. Elekwa, N. \& Eme Okechukwu (2014).Internal Revenue Leakages Prevention and Control in the Local Government System. Global Journal of Management and Business Research: A Administration and Management, 14 (4), Version 1

5. Eme, Okechukwu Innocent; Chukwurah, Daniel C. \& Emmanuel N Iheanacho (2015).Addressing Revenue Leakages In Nigeria. Arabian Journal of Business and Management Review (OMAN Chapter) Vol. 5, No.4; November. 2015

6. Enofe,A. O.; O. R. Aigboduwa, G. O. Audu\& N. G. Idemudia (2015).Integrity, Transparency and Accountability and the Nigerian Local Government. Journal of Political Science and Leadership Research, 1 (8)
7. Izedonmi, F. \& Ibadin, P. (2013). International public sector accounting framework, regulatory agencies and standard setting procedures: A critique. European Journal of Business Management, 5 (6), 17 - 24.

8. Makinde, J. T. (2003). Philosophical approach to the problem of ethics and accountability in the Nigerian public service. In O. E. Ezeani (Ed.), Public accountability in Nigeria: Perspectives and issues. Enugu, Academic Publishing Company.

9. Nwekeaku, Charlie Eke (2013). Revenue Enhancement and National Corporate Objectives in Nigeria. American Journal of Humanities and Social Sciences, Vo1. 1, No. 4, 2013, 251-257

10. Okoh, L. and Ohwoyibo, O. (2010). "Public Accountability: Vehicle for Socio-Economic Development of Nigeria", International Journal of Investment and Finance, 3(1 \& 2): 145-149.

11. Olawale, Rotimi (2016).Accountability \& Transparency: Roles of Government, Parliament, Civil Society Culled from www.youthhubafrica.org

12. Olubunmi, A. D., \& Adesopo, A. A. (2017).Public Financial Accountability Institutions and Democratic Governance in Nigeria. Canadian Social Science, 13 (11), 1-12.

13. Reinikka, Ritva \& Jakob Svensson (2001).Explaining Leakage of Public Funds. The World Bank Development Research Group Public Services for Human Development, November Policy Research Working Papers 2709

14. Utomi, P., Duncan, A., \& Williams, G. (2007).Nigeria and the political economy of reform: Strengthening the incentives for economic growth. The Policy Practice Limited, 33Southdown Avenue, Brighton BN1 6EH, UK. 